\title{
Emergency Nurses' Perceptions of Supportive Behaviors and Burdens in Providing End-Of-Life Care
}

\author{
Santi Ariyanti, Etika Emaliyawati, Ristina Mirwanti \\ Fakultas Keperawatan Universitas Padjadjaran \\ Email: santi14004@mail.unpad.ac.id
}

\begin{abstract}
The high mortality rate in the Emergency Department (ED) is consistent with the high demand for the end of life (EOL) care. However, ED work system required to live-saving quickly and precisely. It affects the quality of EOL care. The purpose of this study was to determine nurses' perceptions in ED related to supportive behaviors (SB) and burdens in providing EOL care to dying patients. The descriptive-quantitative method was used with a cross-sectional approach in 50 nurses Emergency Department at one of the tertiary hospitals in Indonesia. The samples were chosen using the total sampling technique. Data collection used emergency nurse perceptions of end of life care questionnaire. Data were analyzed using univariate analysis in the form of distribution, frequency, and mean. The result of the study showed that the three largest obstacles in EOL care were: ED nurses' work loads (mean=10.626), intra-family disagreements (mean=9.802), and deal with angry of family members (mean=9.472). The three largest supportive behaviors were teaching families how to act (mean=11.962), allowing family members adequate time with the patient after a patient died (mean=11.09), and good collaboration from health professionals (mean=10.886). According to this research, further studies are needed to minimize obstacles and improve supportive behaviors related to the nurse's workload, the provision of spiritual teams, special training for the nurse and the provision of special rooms for EOL patients and their families.
\end{abstract}

Keywords: Burdens, Emergency department (ED), end of life (EOL), nurse emergency department, supportive behaviors. 
Santi Ariyanti: Emergency Nurses Perceptions of Supportive Behaviors and Burdens

\section{Introduction}

The Emergency Services (ED) reported the high of treatment needs and mortality rates in several countries such as in the United States (Smith et al., 2012), United Kingdom (Bailey, Murphy, \& Porock, 2010), and Indonesia (Minister of Health, 2009). The high mortality rate in the ED indicates that the end of life (EOL) treatment is needed in the room. EOL care defines as care or support provided by health professionals to help someone at the terminal stage, so they spend the best time of the rest of their lives and had dignified death as their expectations (National Health Service [NHS], 2015). EOL treatment is given before the main vital function of the heart stops working, given for several hours, or days to patients that diagnosed at the final stage of life and has shown a negative response to the treatment due to a progressive disease that cannot cured, or an acute lifethreatening condition (General Medical Council, 2010). The care provided by nurses including physical, psychological, social and spiritual needs for patients and their families (Warnes, Blackburn, \& Hooper, 2017).

Research in the United States, Australia and Indonesia reveals that the implementation of EOL care at the ED has not been optimal and focuses on meeting physical needs such as oxygen delivery, fluid delivery, and pain medication (Beckstrand, Rohwer, Luty, Macintos, \& Rasmussen, 2015; Decker , Susan, \& Julia, 2015; Ose, Ratnawati, \& Lestari, 2016). EOL treatment is an important treatment for patients and their families because it can affect the quality of life of patients and their families (Stoppelenburg, Rietjens, \& Heide, 2014), and may influence patients' family perspectives on future deaths (NHS, 2015). the implementation of EOL care is also one of the responsibilities of nurses as health workers who interact a lot with patients and families (International Council of Nurses, 2012).

EOL care is a behavior that requires strong intentions or desires. The stronger the intention, the more likely the behavior is done. According to Ajzen (2005), there are three factors that influence a person's intention to behave, including attitudinal factors, subjective norms, and individual self-confidence factors. Of the three factors, the self-confidence factor is determined by individual perceptions of barriers and supportive behavior as a factor that contributes greatly to individual behavior in the context of behavioral research and nurses who perform EOL care (Ajzen, 2005).

Considering the importance of EOL care, there are reports on the ineffectiveness of optimal EOL treatment in several countries including Indonesia and research in Indonesia is still limited, researchers are interested in examining nurses' supportive barriers and behaviors in implementing EOL care at the ED The purpose of this study was to identify the size, frequency, and magnitude of barriers and supportive behavior felt by nurses in implementing EOL care at the ED

\section{Methods}

The method of this research was quantitative descriptive with a cross-sectional approach. Data were analyzed using univariate analysis techniques, and presented in the form of distribution and frequency tables, especially for sociodemographic data, and mean for obstacle variables and supportive behavior. The population in this study was an active nurse in the emergency department of one of the tertiary hospitals in Indonesia on April 7-22, 2018, a total of 51 people. The sampling technique used was total sampling, there was one respondent who was not willing to participate in the study, so the number of samples was 50 (response rate of 98\%). This study has received ethical approval from the ethics committee of the RSUP Dr. Hasan Sadikin Bandung with letter number LB.04.01 / A05 / EC / 052 / III / 2018.

The research variables were nurses' perceptions related to barriers and supportive behavior in implementing EOL care at the ED. This study used an instrument in the form of a questionnaire namely "nurse perceptions of end of life care" developed by Beckstrand, Smith, Heaston, \& Bond (2011). The questionnaire consisted of 28 statements related to barriers and 23 statements related to supportive behavior. The questionnaire was translated into Indonesian through the back translation procedure, then tested the 
Santi Ariyanti: Emergency Nurses Perceptions of Supportive Behaviors and Burdens

validity and reliability test. Validity test is done using content and face validity methods. The validity test results stated that the questionnaire can be understood and can be used. Reliability test results showed that this questionnaire has a Cronbach alpha value of 0.945 for resistance and 0.938 for PS. This showed that the end of life care instruments can be used and reliable.

\section{Results}

\section{Demographic data}

Table 1 Characteristic of Respondents $(n=50)$

\begin{tabular}{|c|c|c|c|}
\hline No & Respondent & Frequency (f) & Percentage (\%) \\
\hline \multirow[t]{4}{*}{1} & Age & & \\
\hline & 21-40 & 33 & 66 \\
\hline & $41-60$ & 9 & 18 \\
\hline & No answer & 8 & 16 \\
\hline \multirow[t]{4}{*}{2} & Gender & & \\
\hline & Male & 17 & 34 \\
\hline & Female & 30 & 60 \\
\hline & No Answer & 3 & 6 \\
\hline \multirow[t]{4}{*}{3} & Work experience at IGD & & \\
\hline & $\leq 5$ & 3 & 6 \\
\hline & $6-10$ & 16 & 32 \\
\hline & $>10$ & 31 & 62 \\
\hline \multirow[t]{3}{*}{4} & $\begin{array}{c}\text { History of training on } \\
\text { emergency }\end{array}$ & & \\
\hline & No & $\mathbf{0}$ & $\mathbf{0}$ \\
\hline & Yes & 50 & 100 \\
\hline \multirow[t]{3}{*}{5} & $\begin{array}{c}\text { History of training on } \\
\text { EOL/Paliatif }\end{array}$ & & \\
\hline & No & 43 & 86 \\
\hline & Yes & 7 & 14 \\
\hline \multirow[t]{3}{*}{6} & Education & & \\
\hline & $\begin{array}{c}\text { Vocational/Diploma in } \\
\text { Nursing }\end{array}$ & 30 & 60 \\
\hline & $\begin{array}{c}\text { Bachelor and Profession } \\
\text { (Ners) }\end{array}$ & 20 & 40 \\
\hline \multirow[t]{4}{*}{7} & $\begin{array}{c}\text { Total of patients with } \\
\text { EOL care }\end{array}$ & & \\
\hline & $\leq \mathbf{5 0}$ & 29 & 58 \\
\hline & $51-100$ & 2 & 4 \\
\hline & $>100$ & 11 & 22 \\
\hline
\end{tabular}

The majority of respondents $(n=50)$ were between 21-40 years old, namely 33 respondents $(66 \%)$, female respondents were 30 respondents $(60 \%)$, working in the emergency room for more than 10 years were 31 respondents $(62 \%)$, emergency training was attended by 50 respondents $(100 \%)$, 43 respondents $(86 \%)$ never attended EOL / palliative care training, the majority of respondent 30 respondents $(60 \%)$ attended Diploma 3 of Nursing degree, and 29 respondents $(58 \%)$ had provided EOL care to less than 50 patients. Information related to demographic data is presented in table 1 . 


\section{Obstacles in the Implementation of EOL Care}

The researchers grouped barriers based on the sources of barriers presented in table 2 . The researcher describes the size, frequency, and barriers / PS, by multiplying the mean size and frequency of occurrence, then sorted from the highest to the lowest rank based on the mean value. The three biggest barriers perceived by nurses were external factors, especially environmental conditions and IGD policies including IGD nurses who had high workloads $($ mean $=10.626)$, two other burdens were related to patients' families, which are family disagreement related to the use of life aids (mean $=9.802$ ) and family members who angry with patients' conditions $($ mean $=9.472)$. The results regarding supportive behavior are described in table 3 .

\section{Supportive Behavior in the Implementation of EOL Care}

The three biggest supportive behaviors from external factors included two items related to the patient's family and one item related to health professionals. Two items of supportive behavior regarding the patient's family include teaching family members about being around the patient when the patient is dying (11.962), giving the family enough time to be with the patient after the patient's death (11.09). The external factor related to health workers was good cooperation from health workers during resuscitation of dying patients (10.886).

\section{Discussion}

Barriers in the Implementation of EOL Care The first barrier is related to the high workload of IGD nurses. The same results are found in several studies conducted by Heaston et al (2006), Beckstrand et al (2008), and KaMing Ho (2016). The three studies stated that the high workload in the ED was the first major barrier item perceived by nurses in implementing EOL care. Furthermore, in Decker, Susan, \& Julia (2015) research using group discussion methods on 25 IGD nurses in Australia mentioned that the high workload in the ED was one of the biggest obstacles in implementing EOL care. The biggest reason is that high workloads reportedly may affect the availability of time that nurses have, so nurses have difficulty providing adequate EOL care to patients and their families.

Nurse workload is defined as the work volume of nurses in a hospital unit, the nurse's work volume is the time needed to handle patients per day (Hendianti, 2012). Excessive workload has a bad effect on the quality of services or care provided (Unanski \& Rentanen, 2016). Khan \& Lai (2010) explain that high workload is often associated with an imbalance in the number of patients and nurses. The existence of this imbalance causes nurses difficulty to provide care to EOL patients optimally, emergency health workers including nurses are required to provide care based on the scale of the emergency, so EOL patients with low emergency levels are often not priority patients.

The second barrier is disagreement in the family related to the use of life aids with a mean value of 9.802 . Similar studies were conducted by Heaston et al (2006), Beckstrand et al (2008), and Ka-Ming Ho (2016), these studies found that disagreements in families related to the use of life aids were not the biggest obstacle perceived by nurses in implementing EOL care. This item might be the biggest obstacle item because it can affect the length of time and effectiveness of the treatment provided (Heaston et al., 2006).

One example of the family barrier is that a patient showed signs of respiratory failure and required the installation of an endotracheal tube (ETT) immediately. Then, the nurse asks for family approval, but the decision is taken a long time because of the family disagreement, and it would be impacted by the nursing care plan. Disagreements within the family have spent the nurse's time because nurses must assist and ensure informed consent. Nurses and other health workers must follow up on family decisions and consent, and subsequently, have an impact on increasing the emergency workload of the ED. The similar condition is common in Indonesia, where the majority of the population is extended family, and the decision making considers the opinions of the extended families (Effendy, 1998). The role of the nurse as an advocate is needed to 
help and facilitate the family to make the best decisions in emergency conditions.

The third burden is facing family members'angry with a value of 9,472 . This finding in line with studies' of Heaston et al (2006), Beckstrand et al (2008), Beckstrand et al (2015) and Ka-Ming Ho (2016). Families who are angry when nurses have to provide interventions at the emergency room would interfere with the nurse's care plans. Beckstrand et al (2008) stated that dealing with angry of family members who cannot accept the patient's condition, or being shocked by sudden deterioration often makes the situation in the ED is chaotic and results in a mismatch of treatment plans, nurses spend time to explain the situation or patient terminology to the family so that emotions or anger from family members decline. Nurses are required to be able to do good therapeutic communication with limited time to deal with angry of family members. Therapeutic communication to the patient's family is important because the family is one part of the patient may affect the implementation and success of treatment.

\section{Supportive Behavior in the Implementation of EOL Care}

The first supportive behavior is to teach family members about how to behave around a patient when the patient is dying, with a value of 11,962 . This item is also the five largest supportive behavior in the research conducted by Beckstrand et al (2008), Beckstrand et al (2010), and Attia, Abd-Elaziz, \& Kandeel (2013). Nurses teach families about how to behave around patients when patients face death such as teaching families to keep asking patients to communicate because patients are still listening and teaching families to guide patients by saying talqin sentences for Muslims or other sentences according to their religion and beliefs. It is also possible to help families to be better prepared to deliver patients to a peaceful and dignified death

The second supportive behavior is to provide sufficient time for the family to be with the patient after the patient's death, with a value of 11.09. In several studies by Heaston et al (2006), Beckstrand et al (2008), Beckstrand, et al (2010), Beckstrand, et al (2012), and Ka-Ming Ho (2016) this item belongs to the three biggest supportive behaviors. Giving sufficient time for the family to be with the patient after the death of the patient is one of the post-EOL care. The nurse should provide help to the family to go through the grieving phase. Sufficient time after the patient's death would help the family to express their feelings, be reconciled with emotions and fully accept the loss of their family members (Department of Health, 2008). The role of nurses as facilitators in this phase is very much needed especially to facilitate a calm environment and sufficient privacy so that families can freely express their feelings. They also needed facilities including a special room to minimize expressions/expressions/ feelings of the family seen or heard by patients or other families.

Supportive behavior items are about the good cooperation of health professionals during resuscitation of dying patients with a mean of 10,886 . This item is not one of the biggest supportive behaviors, but it can be one of the supportive behaviors due to the good collaboration of nurse, midwife and ambulance technicians.

\section{Conclusion}

The identified barriers and supportive behaviors perceived by nurses in providing EOL care at the ED are expected there would be actions to minimize barriers and increase existing PS, such as further studies of nurses' workload, providing a spirituality team, special training for nurses in providing EOL care and providing of special rooms for EOL patients and their families. This research is the initial data relating to barriers and supportive behavior that nurses perceive in implementing EOL care. Future researchers may develop more in-depth research and studies of items that become barriers or supportive behaviors. In this study, the instrument used has not been carried out by construct validity test, so it is expected that if there are similar researchers, then they would do the construct validity test so that the instruments used are truly valid and reliable. 
Santi Ariyanti: Emergency Nurses Perceptions of Supportive Behaviors and Burdens

\section{References}

Ajzen, I. (2005). Attitude, Personality, and behavior. In T. Manstead (Ed.) (2nd ed.). New York: USA: Open. University Press.

Attia, A. K., Abd-Elaziz, W. W., \& Kandeel, N. A. (2013). Critical Care Nurses' Perception of Barriers and Supportive Behaviors in Endof-Life Care. American Journal of Hospice and Palliative Medicine, 30(3), 297-304. https://doi.org/10.1177/1049909112450067.

Bailey, C., Murphy, R., \& Porock, D. (2010). Trajectories of End-of-Life Care in the Emergency Department. YMEM, 57(4), 362-369. https://doi.org/10.1016/j. annemergmed.2010.10.010.

Beckstrand, R. L., Collette, J., Callister, L., \& Luthy, K. E. (2012). Oncology Nurses' Obstacles and Supportive Behaviors in Endof-Life Care: Providing Vital Family Care. Oncology Nursing Forum, 39(5), E398E406. $\quad$ https://doi.org/10.1188/12.ONF. E398-E406.

Beckstrand, R. L., Rawle, N. L., Callister, L., \& Mandleco, B. L. (2010). Pediatric nurses' perceptions of obstacles and supportive behaviors in end-of-life care. American Journal of Critical Care, 19(6), 543-552. https://doi.org/10.4037/ajcc2009497.

Beckstrand, R. L., Rohwer, J., Luthy, K. E., Macintos, J. L. B., \& Rasmussen, R. J. (2015). Rural Emergency Nurses' End-OfLife Care Obstacle Experiences: Stories From The Last Frontier. YMEN, 1-9. https:// doi.org/10.1016/j.jen.2015.08.017.

Beckstrand, R. L., Smith, M. D., Heaston, S., \& Bond, A. E. (2008). Emergency Nurses' Perceptions of Size, Frequency, and Magnitude of Obstacles and Supportive Behaviors in End-of-Life Care. Journal of Emergency Nursing, 34(4), 290-300. https:// doi.org/10.1016/j.jen.2007.09.004.

Chan, Z. C. Y., \& Lai, W.-F. (2010). A Hong Kong perspective on ways to improve nurse retention. Nursing Standard: Official Newspaper of the Royal College of Nursing,
24(35), 35-40. https://doi.org/10.7748/ ns2010.05.24.35.35.c7750.

Decker, K., Susan, L., \& Julia, M. (2015). The experiences of emergency nurses in providing end-of-life care to patients in the emergency department. Australasian Emergency Nursing Journal, 18(2), 68-74. https://doi.org/10.1016/j.aenj.2014.11.001.

Departmen of Health. (2008). End of Life Care Strategy : Promoting High-Quality Care For All Adults At The End Of Life. Retrieved from http://www.cpa.org.uk/cpa/End_of_ Life_Care_Strategy.pdf.

Effendy, N. (1998). Dasar-Dasar Keperawatan Kesehatan Masyarakat (2nd ed.). Jakarta: EGC.

General Medical Council. (2010). Treatment and care towards the end of life: good practice in decision making. General Medical Council, 1-85. https://doi.org/978-0-90145846-9.

Hanratty, B., Holmes, L., Lowson, E., Grande, G., Addington-hall, J., Payne, S., \& Seymour, J. (2012). Older Adults Experiences of Transitions Between Care Settings at the End of Life in England: A Qualitative Interview Study. Journal of Pain and Symptom Management, 44(1), 74-83. https://doi. org/10.1016/j.jpainsymman.2011.08.006.

Heaston, S., Beckstrand, R. L., Bond, E., Palmer, S. P., Provo, \& Utah. (2006). Emergency Nurses' Perceptions of Obstacles and Supportive Behaviors in End-of-Life Care, (December). https://doi.org/10.1016/j. jen.2006.07.013.

Hendianti, G. N. (2012). Gambaran Beban Kerja Perawat Pelaksana Unit Instalasi Gawat Darurat Rumah Sakit Muhammadiyah Bandung. Students E-Journal, 1(1), 31.

International Council of Nurses. (2012). The Code of Ethics for Nurses. The Michigan Nurse, 74(2), 9-10. https://doi. org/10.1111/j.0028-1425.2007.ethics.x.

Ka-Ming Ho, J. (2016). Resuscitation versus 
Santi Ariyanti: Emergency Nurses Perceptions of Supportive Behaviors and Burdens

end-of-life care: Exploring the obstacles and supportive behaviors to providing end-of-life care as perceived by emergency nurses after implementing the end-of-life care pathway. Applied Nursing Research, 29, e7-e13. https://doi.org/10.1016/j.apnr.2015.05.014.

Menteri Kesehatan RI. (2009). Keputusan Menteri Kesehatan Republik Indonesia Nomor 856 / Menkes / SK / IX / 2009 Tentang Standar Instalasi Gawat Darurat ( IGD ) Rumah Sakit. Retrieved October 9, 2017, from http://sardjitohospital.co.id/sardjitowp/ wp-content/uploads/2015/12/kepmenkes856-thn-2009-standar-IGD.pdf.

National Health Service. (2015). End of life care. Retrieved February 5, 2017, from https://www.nhs.uk/Planners/end-of-lifecare/Pages/what-it-involves-and-when-itstarts.aspx.

Ose, M. I., Ratnawati, R., \& Lestari, R.
(2016). Studi Fenomenologi Pengalaman Perawat Instalasi Gawat Darurat (Igd) Dalam Merawat Pasien Terlantar Pada Fase End Of Life Di Rsud Dr. Saiful Anwar Malang, 4(2).

Smith,A. K., McCarthy, E., Weber, E., Cenzer, I. S., Boscardin, J., Fisher, J., \& Covinsky, K. (2012). Half of older Americans seen in the emergency department in the last month of life; most admitted to the hospital, and many die there. Health Affairs, 31(6), 1277-1285. https://doi.org/10.1377/hlthaff.2011.0922.

Stoppelenburg, A. B., Rietjens, J. A. C., \& Heide, A. Van Der. (2014). The effects of advance care planning on end-of-life care : A systematic review, (Erasmus MC). https:// doi.org/10.1177/0269216314526272.

Warnes, G., Blackburn, K., \& Hooper, J. (2017). Wiltshire 's End of Life Care Strategy For Adults 2017 to 2020. 